\title{
Oblicza przemian w Sztukach Pięknych
}

\section{Katarzyna Stanny}

(Akademia Sztuk Pięknych w Warszawie)

Warunkiem trwatości jest przemiana - to mądre i wiecznie aktualne credo stało się tematem XXII serii „Napisu” (20I6), a także inspiracją dla studentów Pracowni Obrazowania dla Mediów, którą prowadzę na Wydziale Sztuki Mediów warszawskiej ASP.

Pisząc o przemianach w Sztukach Pięknych, starałam się możliwie szeroko ukazać bogaty i niezwykle różnorodny wachlarz tych zjawisk. Przemianę materii rzeźbiarskiej czy malarskiej w dzieło sztuki, metamorfozę duchową artysty podczas tworzenia dzieła oraz publiczności podczas jego odbioru. Zjawiska te zachodzić mogą także na płaszczyźnie wiary, za pomocą przekazu o czysto religijnym charakterze.

„Starzenie się” dzieła lub przeciwstawiające mu się zabiegi konserwatorskie są przykładami zmian zachodzących na poziomie materialnym, dzięki technologii zmieniającym percepcję dzieła w czasie, natomiast sztuka podporządkowana wychwalaniu - i wywoływaniu - społecznych ewolucji oraz rewolucji pełni rolę służebną wobec propagandy i polityki.

Wizje artystyczne często bywają uzależnione od wpływu substancji psychoaktywnych na świadomość twórcy i jego percepcję rzeczywistości, co powoduje zupełnie inny jej odbiór. Czy zatem wizja artystyczna dzieła powstałego pod ich wpływem jest obiektywna? Gdzie i czy w ogóle we współczesnym świecie przebiegają granice pomiędzy sztuką a nie-sztuką? Na te pytania i wątpliwości starałam się znaleźć odpowiedź w tekście zatytułowanym Oblicza przemian w Sztukach Pięknych.

Artysta jest swego rodzaju medium twórczym, podlegającym ciągłym przemianom, które wynikają z niezwykle bogatej sfery duchowej, będącej podstawowym perpetuum mobile, jakie napędza inspirację niezbędną do stworzenia dzieła. Aby powstało dzieło sztuki czy choćby jakikolwiek przekaz artystyczny, potrzebna jest niezwykła wrażliwość na otaczającą rzeczywistość oraz umiejętność nie tylko 
dostrzeżenia najbardziej wartościowych jej aspektów, ale przede wszystkim zdolność do tego, by potrafić przenieść ją właśnie w sferę sztuki. Tworząc, poprzez dzieło ukazujemy swoją duszę, dokonując obnażenia najbardziej jej intymnych zakątków. Obiekt sztuki staje się poniekąd autoportretem naszej duchowości, aktualnych przeżyć, emocji, stanu umysłu, zaangażowania w pozornie najdalsze od realizowanego tematu kwestie, które tak naprawdę stają się niezwykle bliskim ich doświadczaniem. Artysta wchodzi w osobistą relację z powstającym obiektem; tego dialogu uczuć, myśli i emocji nikt poza nimi nie usłyszy. Dopiero dzieło ukończone przemówi ich wspólnym głosem, odkrywając jednak tylko część omawianych w tym sekretnym dialogu treści.

Istnieje taki proces twórczy, którego wynikiem bywa przemiana duchowa po ukończonej pracy. Przemiana ta może być także powodem do tworzenia, formą terapii czy też dialogu z samym sobą. Wówczas sztuka pełni rolę medium, pozwalającego na uwalnianie emocji i uczuć, nawiązując niekiedy do sztuki prymitywnej, sztuki dziecka czy osób psychicznie obciążonych przez chorobę. Przykładem może być malarstwo i rzeźba dwudziestowiecznego francuskiego artysty Jeana Dubuffeta (I9OI-1985).

\section{》Twórczość Dubuffeta miała charakter świadomej prowokacji, fron- talnego ataku na subkulturę mieszczańską, ale także na wszelkie ste- reotypy funkcjonujące w społeczeństwie. \\ Szczególne wzburzenie wywołała wystawa „Corps de Dames” (Cia- ła pań) z I950. Od I947 tworzył kolekcję art brut (sztuki surowej), gromadząc twórczość umysłowo chorych, prymitywne grafiki itp. Swe poglądy wypowiadał w wielu publikacjach, m.in. w „Prospekcie dla wszelkiego rodzaju amatorów”, w którym apelował o tworzenie dzieł sztuki powszechnie zrozumiałej, spontanicznej, uwolnionej od wszelkich konwencjonalnych stylistyk ${ }^{\mathrm{T}}$.}

Wspomniana wyżej przemiana dokonuje się na polu duchowym, które stanowi niezwykle istotny czy może nawet najważniejszy punkt wyjścia do powstania obiektu sztuki. Na kolejnym etapie nie mniej ważna jest transformacja czysto fizyczna, przemiana materiałów będących jedynie przedmiotami służącymi do wykrzesania z nich Dzieła, które powstać może nie tylko dzięki konsekwentnej lub spontanicznej pracy, ale także dzięki symbolicznej „iskrze Bożej”, która dłońmi i talentem artysty przemienia np. kamień w rzeźbę. 
Najpełniej widać to właśnie w rzeźbie, gdzie materia wymaga największego nakładu sił fizycznych, aby przekształcić surowiec kamiennego bloku, gliny, metalu czy drewna na przykład w zapierające dech w piersiach marmurowe posągi dłuta Michała Anioła (I475-I564).

\Marmur leżał wciąż płasko na ziemi. Zrobił drewnianą konstrukcję odpowiedniej długości, na jej boku zawiesił sznurki obciążone ołowiem, pokazujące, na jakiej głębokości bloku ma szukać głowy Dawida, ramienia wyciągniętego, aby wziąć procę, bioder, kamienia w jego potężnej prawicy, pnia drzewnego podtrzymującego prawą nogę. Zaznaczył te punkty węglem; potem wziąwszy piętnastu ludzi Beppe owiązał linami kolumnę, podniósł ją przy pomocy bloku i wielokrążka i ustawił pionowo na stole obrotowym Sangalla. Razem z Argientem wybudowali wieże rusztowania z otwartymi półkami, do których można było wkładać szerokie deski na każdej wysokości, jaka mu będzie potrzebna do pracy.

Teraz kolumna wzywała go, oddając mu się cała. Jego narzędzia wdzierały się w nią, z przerażającą gwałtownością szukały ramion i ud, klatki piersiowej, krocza i rzepki kolanowej. Czekające od pół wieku uśpione białe kryształy poddawały się miłośnie każdemu dotknięciu, od najłagodniejszego pogładzenia do gwałtownego zrywu, w którym jego młotek i dłuto jak gdyby ślizgały się w górę od kostki nogi przez kolano i udo bez zatrzymania, już nie zwykłym, stałym rytmem, tylko szybko, gwałtownie, bez wypoczynku - bo czuł w sobie siłę olbrzyma. Było to jego najwspanialsze przeżycie przy rzeźbieniu w marmurze: nigdy przedtem nie miał tak ogromnego posągu, takiej prostoty planu; nigdy przedtem nie był obdarzony takim poczuciem precyzji, siłą, wnikliwością; opanowany tak głęboką pasją. [...] Przez dwadzieścia godzin dziennie zaspokajał swój głód marmuru, przez dwadzieścia godzin palący pył marmurowy gęstniał mu w nozdrzach i pokrywał włosy, aż stawały się białe jak Ficina, przez dwadzieścia godzin drżenie marmuru spływało z dłuta i młota w jego ramiona, klatkę piersiową, lędźwie, uda i kolana, hucząc i wirując w ciele i mózgu jeszcze w długi czas potem, gdy w radosnym wyczerpaniu rzucał się na posłanie ${ }^{2}$.

Rodzące się przemiany duchowo-fizyczne zachodzą nie tylko w „stwórcy” dzieła, ale także w jego odbiorcy, który przez kontakt zmysłowy chłonie przekaz, jaki za- 
warł w nim artysta. Przekaz ten nie zawsze jest tożsamy z pierwotną ideą tego, co nadawca zawarł, i tego, co odbiorca odebrał. W tym wypadku działają dwie sfery ludzkiej emocjonalności, ukryte w co najmniej dwóch postaciach pochylających się nad obiektem rzeźbiarskim, malarskim, fotograficznym, filmowym czy każdym innym, jaki w czasach nam współczesnych zostanie zakwalifikowany do rangi „dzieła sztuki”. Poprzez samo swoje istnienie w świecie tak stworzony obiekt, jak i artysta, mogą wpływać na dokonywanie się kolejnych przemian zachodzących zarówno w dekadach nadchodzącej dopiero historii sztuki, jak i metamorfoz będących pochodną ich istnienia i oddziaływania w obrębie rzeczywistości.

Wiele zależy również od ekspozycji obiektu, dla którego kameralność lub zamierzony jej brak przez osadzenie w przestrzeni publicznej mają niezwykle istotne znaczenie. Obcowanie z obrazem takim jak np. Mona Lisa Leonarda da Vinci (I452-I519), eksponowanym w głośnej, pełnej turystów sali muzeum paryskiego Luwru, według moich odczuć w ogromnej mierze pozbawia ten obraz zarówno magii, jak i pełnej skupienia duchowości, które z pewnością towarzyszyły artyście w pracowni podczas jego powstawania. Odarta $\mathrm{z}$ aury zacisznego wnętrza, narażona na nieustanne błyski agresywnych lamp aparatów fotograficznych, Mona Lisa jest jakby zamknięta w publicznym mauzoleum niegodnym swej przyznanej na przestrzeni epok najwyższej rangi.

Powszechnie znana szerokim odbiorcom Gioconda nie jest bynajmniej jedynie portretem kobiety pełnej tajemnicy:

\ Leonardo ustawicznie pyta o sytuację człowieka w świecie. Jedną z możliwych odpowiedzi malarz zdaje się wyrażać poprzez niezrównany uśmiech Mony Lisy, uśmiech, który jest znakiem pełnej ironii świadomości samego siebie, ,ja”, które pojęło śmiertelny charakter swego bytu, wpisanego w porządek nieskończoności natury. Z twarzy Giocondy bije, oparta na paradoksie, mądrość - pełna spokojnej wytworności, niepozbawiona jednak niepokoju. Nie jest to uśmiech promienisty, lecz delikatny, ledwie obecny, jakby zawieszony. Jak zauważa niemiecki filozof Karl Jaspers (1883-1969), Gioconda „łagodzi napięcie” między jednostką a naturą, czasem i śmiercią, życiem i rozkładem³.

Czym innym jest odbiór Ostatniej Wieczerzy, również autorstwa Leonarda da Vinci, będącej od zawsze w tym samym miejscu. Powstającej na widoku publicznym kompozycji grupy postaci, dla których przecież sama tematyka wiąże się z określonym przesłaniem dla zebranych wiernych: 
\ Najwybitniejszym dziełem okresu mediolańskiego jest „Ostatnia Wieczerza" 1495-95 (Mediolan, refektarz w S. Maria delle Grazie), malowidło ścienne wykonane eksperymentalnie farbami olejnymi i temperą, które źle znosiło wilgotne, wapienne podłoże ściany i zaczęło odpadać już za życia Leonarda. Uznawane od początku za szczytowe osiągnięcie jego malarskiej twórczości do dziś uchodzi za dzieło doskonałe, kopiowane przez niezliczonych artystów, opisywane przez poetów i podziwiane przez widzów - nawet jeśli jest tylko niepewnym echem oryginalnego efektu. Częste próby restauracji dzieła wpłynęły nań raczej niekorzystnie. (W I986 „Ostatnia Wieczerza” po długich badaniach została znów oczyszczona i zrekonstruowana. Ze względu na zaskakująco mocną kolorystykę wynik prac poddano krytyce). Zasiadający po jednej stronie stołu apostołowie zebrani są w trzyosobowe grupki i symetrycznie rozmieszczeni po obu stronach Chrystusa. [...] Mimo nie najlepszego stanu fresku, co jest efektem użycia mało odpornych na wilgoć barwników, widać z jaką subtelnością udaje się artyście wyrazić nie tylko zewnętrzne zachowanie, ale i reakcje wewnętrzne każdego $\mathrm{z}$ apostołów. Z łatwością odczytać można $\mathrm{z}$ ich twarzy - zdumienie, złość, rezygnację, niedowierzanie, smutek. Wszyscy są wyraźnie wzburzeni; wszyscy, z wyjątkiem Judasza, który siedzi nieruchomy, samotny, jakby nieobecny.

Między kolorami, formami, gestami i spojrzeniami panuje prawdziwa harmonia, a ogólne poruszenie przedstawione jest w sposób bardzo przemyślany. Całość utrzymana jest w ciemnej tonacji. Według Stendhala ów „styl czarny i pełen majestatu” całkowicie odpowiada tej religijnej scenie $e^{4}$.

Metamorfoza tego niewątpliwie wielkiej klasy dzieła sztuki, zmieniającego się wraz z upływającym czasem, dokonała się dzięki technologii. Przygaszona, utrzymana w ciepłej gamie miodowych ugrów Ostatnia Wieczerza, odsłonięta po zabiegach konserwatorskich w 1986 roku mocno zaskoczyła jej odbiorców. Po zdjęciu kolejnych warstw substancji utrwalających, oczyszczeniu płaszczyzny malarskiej oraz odpowiednim, ponownym jej zabezpieczeniu, ukazała się zupełnie nowa jej odsłona, tak bardzo odbiegająca od wpisanej w świadomość klasyki włoskiego malarstwa. Kolory stały się jaśniejsze, bardziej jaskrawe i kontrastowe. Ta zmiana, jaka zaszła dzięki nowoczesnym technologiom konserwatorskim, stała się w istocie jakby odwróceniem strumienia czasu, powrotem do istnienia w swej pierwotnej 
formie. Podobnym zaskoczeniem są stosowane na budynkach mappingi czy iluminacje świetlne. Przykładem takich zabiegów jest fasada romańskiego kościoła Notre-Dame la Grande (XII w.) w Poitiers, stolicy francuskiego regionu Poitou-Charentes. Upływ czasu i wpływ warunków atmosferycznych spowodowały, że przyzwyczailiśmy się do obcowania ze swego rodzaju płaskorzeźbą, niezwykle bogatą w architektoniczno-rzeźbiarskiej formie, jednak całkowicie pozbawioną koloru.

Za dnia budynek przypomina monochromatyczny, jednolity w gamie barwnej zamek z piasku, zupełnie spłukany z istniejącej niegdyś barwnej polichromii. Dzięki zastosowaniu współcześnie dostępnych efektów świetlnych możemy podziwiać fasadę w jej pełnej krasie, niemalże tożsamą z tym, jak bogato kolorystycznie była zdobiona wówczas, kiedy powstała. Czas dokonał przemiany, pewnego rodzaju degradacji kolorystycznej, która - podobnie jak na przykładzie Ostatniej Wieczerzy - w pewnym sensie uszlachetniła ten obiekt architektury sakralnej.

W tym miejscu warto wspomnieć o wpływie szeroko rozumianej sztuki sakralnej na przemiany duchowe, jakie dokonują się w jej odbiorcach. Bez względu na epoki, style, zachodzące mody i wszelkie transformacje ustrojowo-społeczne sztuka sakralna pełniła, pełni i prawdopodobnie pełnić będzie tę samą, stałą rolę na przestrzeni dziejów. Jej wieczna obecność w świecie sztuki podlega przemianom estetycznym w obrębie obowiązującego w danym momencie stylu czy kanonu. Rolą jednak nadrzędną tej z pozoru stałej zbiorowości obiektów architektury, rzeźby, malarstwa czy grafiki jest odwołanie się do strony duchowej obcującego z nią odbiorcy, ukazanie sfery religijnej niedostępnej na gruncie ziemskim.

Przykładem niezwykle wyrazistej formalnie postaci rzeźbiarskiego uduchowienia jest Pietà Rondanini (ok. 1555-64) autorstwa Michała Anioła, wykuta w marmurze pod koniec życia artysty, która „ma bardzo osobisty charakter. Jest adresowanym do Boga, a nie do człowieka błaganiem o odpuszczenie win”"

Wywołanie trwogi, refleksji nad przemijalnością ziemskiego bytowania czy wręcz poczucia ludzkiej małości służy zarówno wiernym, jak i instytucji kościoła do osiągnięcia zamierzonego celu, jakim jest chwalenie Boga oraz przekazywanie dogmatów wiary za pomocą obrazów. Stworzenie Adama, fragment fresku Michała Anioła na sklepieniu Kaplicy Sykstyńskiej (1508-I5I2) to jedna z bardziej znanych w ikonografii scen, pełnych duchowej głębi i majestatu:

\section{\Artysta nie pokazał tu aktu kształtowania ciała człowieka, lecz mo- ment, w którym Pan tchnął w niego duszę, moment przepływu boskiej}

5 H.W. Janson, Historia sztuki od czasów najdawniejszych po dzień dzisiejszy, tłumacze różni, Warszawa 1993, s. 427. 
energii. Nikt dotąd nie poważył się na równie dramatyczne zestawienie Boga i człowieka 6 .

Przykładem monumentalizmu w architekturze jest zespół budynków Watykanu (pierwotny projekt Bazyliki św. Piotra wraz z rozbudową Pałacu Watykańskiego), początkowo zaprojektowany przez Donata Bramantego (I444-I5I4), a kontynuowany przez Michała Anioła.

\section{\Sprowadził on zespół sekwencji przestrzennych planu Bramantego do jednego krzyża i kwadratu. Michał Anioł określił główną oś kościoła przez zmodyfikowanie wschodniej apsydy i dobudowanie portyku. Ta część projektu nie doczekała się jednak realizacji. Ideę Michała Anioła w pełni odzwierciedla natomiast kopuła, wzniesiona w dużej mierze po śmierci artysty. Jest ona przeciwieństwem kopuły zaplanowanej przez Bramantego - półkolistej „schodkowej” czaszy na niskim bębnie, przy- tłaczającej kościół swym ciężarem. Kopuła Michała Anioła wystrzela ku górze, jak gdyby wypychana nieposkromioną energią, której źródło znajduje się wewnątrz budowli. Wysoki bęben, mocno zaakcentowane żebra podtrzymywane przez zdwojone kolumny, wysmuklona czasza, latarnia - wszystko to nadaje kopule charakter wertykalny .}

Czy po opuszczeniu okazałych budynków tej świątyni wierny dozna duchowej przemiany, tego nie wiem, ale z pewnością pozostanie pod niezatartym wrażeniem potęgi architektonicznych, malarskich i rzeźbiarskich założeń, jakie były celem twórców tego niezwykle symbolicznego dla chrześcijaństwa miejsca.

Watykan z całym swym demonstracyjnym bogactwem wystroju i wspaniałością odgrywa także (prócz religijnej) rolę państwową, dlatego właśnie opisana powyżej sztuka sakralna bliska jest całemu obszarowi sztuk pięknych, jakie służą gloryfikacji władzy czy określonego systemu politycznego.

Najdobitniejszymi przykładami służy sztuka Egiptu, Trzeciej Rzeszy czy swego rodzaju zabiegi masowe stosowane przez Związek Radziecki i Koreę Północną. Majestatyczne, ogromne w swej nadnaturalnej skali budynki użyteczności publicznej, ogromne portrety zarówno rzeźbiarskie, jak i malarskie przywódców państwowych, kontrastowe zestawienia kolorów czy wręcz identyfikacja wizualna takich ugrupowań, jak np. SS (Die Schutzstaffel der NSDAP, czyli oddział ochronny NSDAP), będąca połączeniem podwojonej runy Sig (przypominającej symbol błyskawicy) 
z czaszką, pełniły ściśle określoną przez ich projektantów funkcję. Celem takich zabiegów było wywołanie wrażenia wielkości władzy, jej imponująco sprawnego działania, a niekiedy nawet budzenie w obywatelach uczucia strachu i jednoczesnego respektu. W tym wypadku nie można w sposób dosłowny mówić o przemianach zachodzących na polu sztuki, ale można dostrzec przemianę, jaka dokonuje się w obywatelach państwa totalitarnego, posługującego się opisanym przeze mnie wizualnym językiem sztuki, mającym na celu wywołanie pewnego konkretnego, społecznie zamierzonego efektu.

Pozostając w tym miejscu i czasie historycznym, należy przywołać pewien jakże trudny do opisania kontekst przemian w sztuce czy raczej w przemyśle, jaki dokonywał się w obozach koncentracyjnych, gdzie materiał ludzki służył do wytwarzania obiektów użyteczności codziennej. Myślę, że trudno byłoby odpowiedzieć jednoznacznie na pytanie, czy tego typu działanie mieści się jeszcze w obrębie ewoluującej sztuki, z pewnością jednak mieści się w obszarze niewyobrażalnie daleko idących zmian w odbiorze ludzkiego ciała jako źródła surowca do wytwarzania torebek czy abażurów. Wstrząsający jest fakt, że produkowane w tamtym czasie z ludzkiej skóry obiekty użytkowe $\mathrm{z}$ dziedziny wzornictwa przemysłowego tym bardziej uznawane były za osobliwe „dzieła”, im bardziej indywidualne nosiły cechy, np. znamiona czy tatuaż. Opisane tutaj przemiany dokonały się w tamtym czasie nie tylko na polu „wzornictwa" i przemysłu hitlerowskich Niemiec, ale przede wszystkim w obszarze ludzkiej świadomości, przesuwania się granic wrażliwości oraz szacunku dla drugiej żywej, myślącej i czującej istoty, aż do ich całkowitego anulowania.

Pozostając w kontekście politycznym, na powojennym już gruncie polskim przykładem działań propagandowych może być obdarowanie Warszawy przez Związek Radziecki Pałacem Kultury i Nauki, wybudowanym w latach 1952-1955 według projektu radzieckiego architekta Lwa Rudniewa. W tym miejscu należy wspomnieć, że ustawienie tak ogromnego budynku w samym centrum pustej, odbudowywanej dopiero z wojennych gruzów stolicy, nie było jedynie neutralnym usytuowaniem, lecz celowym zabiegiem, mającym jednoznacznie określić polityczne wpływy, pod jakimi znalazła się wówczas Polska.

Cała sztuka tamtego okresu, ustanawiając na nowo kulturę ówczesnej państwowości, jednoznacznie zmieniała dogmaty obecne m.in. w sztukach pięknych i literaturze okresu przedwojennego. Zachodzące na tej płaszczyźnie zmiany spowodowały również metamorfozy w relacjach społecznych, co było celem nowo powstającego wówczas państwa socjalistycznego.

Realizm socjalistyczny, jaki wówczas zapanował w sztuce, miał zaszczepiać w narodzie treści nie tylko poprzez formę wizualną, ale przede wszystkim za pomocą kontekstu, jakiego w owym czasie sztuka nabierała. Sceny rodzajowe obecne w 
malarstwie, rzeźbie czy plakacie, przedstawiające pracujący w pocie czoła naród, miały na celu budowanie świadomości wspólnotowej dla całej Polskiej Rzeczpospolitej Ludowej. W tym wypadku szeroko rozumiana propaganda jest narzędziem oraz łącznikiem świata sztuki i władzy, mającym na celu osiągnięcie zamierzonych efektów na skalę państwową i dokonania przemian w społeczeństwie, dla którego stanowi jeden $z$ istotnych elementów edukacji.

Zupełnie innego typu przemiany dzieł sztuki, wyrastające z uważnej obserwacji świata natury, towarzyszą natomiast krajobrazom okresu Młodej Polski; tak piękne, bogate w kolorystycznej gamie pejzaże Jana Stanisławskiego, Józefa Czajkowskiego, Juliana Fałata, Józefa Chełmońskiego czy Stanisława Wyspiańskiego ukazują zmiany pór roku zachodzące w przyrodzie. Ciepło oświetlone zimowe pejzaże z kuropatwami na śniegu czy szumiące, chłodne górskie potoki są niezwykle trafnymi malarskimi interpretacjami przemian natury. Uchwycone z wielką wrażliwością, przybliżają nas do świata natury poprzez ogromną malarską gamę form i barwnych tonów, ukazując jej wyrafinowane piękno.

W tym samym mniej więcej czasie we Francji Claude Monet (I840-I926) dokonuje niezwykle wnikliwej malarskiej obserwacji przemian impresjonistycznych, zachodzących na fasadzie katedry w Rouen (1893-1894). Seria „portretów kolorystycznych" tego dostojnego gotyckiego budynku dokumentuje, jak katedra zmienia się wraz z porami roku i dnia, jak przybiera nieskończenie bogatą gamę barw, uzależnionych od światła obecnego w danym momencie w interpretowanym malarsko miejscu.

\section{W miarę upływu lat Monet kładzie na płótno coraz grubszą warstwę farby, rozbicie kolorów jest mniej widoczne niż na początku twór- czości. Barwy i plamy barwne zlewają się i łączą między sobą. Dzięki temu odnosi się wrażenie, że światło zawarte jest w obrazie. \\ W słońcu i w cieniu, w przejrzystym wiosennym dniu i szarą zimową porą - kamień nasycony jest kolorowymi barwnikami. U Moneta cień staje się światłem, a światło kolorowym rozedrganiem8.}

Pory roku stały się także ważnym motywem dla plakatowych ujęć w niezwykłej twórczości Alfonsa Muchy (I86o-1939). Wyrafinowane i zdobne w bizantyjsko-secesyjne floresy postaci kobiece ukazują kunszt jego grafiki, tak charakterystyczny dla epoki art nourveau. Kolorystyka każdej z pór roku wynika z typowej dla danego okresu aury, barwnej plamy domkniętej - niczym witraż - wysmakowaną linią, 
podsumowującą graficzno-malarskie przestrzenie zachodzących w tym ujęciu przemian natury.

W tym miejscu należy wspomnieć niezwykle ważne dla literatury dzieło, jakim są Chtopi Władysława Stanisława Reymonta (1867-1925), w którym następstwo pór roku (będących zarazem tytułami kolejnych tomów) stanowi główną oś, pięknie budującą fabułę i organizującą obraz świata. Nagrodzona Noblem w 1924 roku powieść doczekała się także przepięknej ekranizacji w I973 roku. Filmowa adaptacja w reżyserii Jana Rybkowskiego to kolejny przykład na niedewaluujące się w żadnej epoce piękno związane $\mathrm{z}$ tematyką życia polskiej wsi, jej folklorem i zachodzącymi na tym tle przemianami codziennej wiejskiej egzystencji, obrzędów i obyczajów.

Przełom XIX i XX wieku to także okres rozkwitu twórczości Stanisława Ignacego Witkiewicza - Witkacego (I885-1939), którego nie sposób byłoby tutaj pominąć w kontekście przemian zachodzących w uprawianej przez niego sztuce, jakie dokonywały się dzięki substancjom narkotycznym, po które sięgał. Założona przez niego w 1927 roku „Firma Portretowa S.I. Witkiewicz” świadczyła usługi w zakresie portretowego ujmowania modela w technice pasteli. Regulamin świadczonych w firmie usług był zarazem swoistym manifestem - wprowadzeniem do twórczości plastycznej Witkacego. Ilość substancji psychoaktywnych oraz ich charakter miały decydujący wpływ na przemianę, jaka dokonywała się w Witkacym i kształtowała jego interpretację pozującego modela.

Oferta firmy obejmowała obrazy podzielone na pięć kategorii:

\ typ A czyli „wylizane”. Odznaczały się niemal fotograficznym podobieństwem do modela, $\mathrm{z}$ reguły jednak posiadały fantastyczne tło, najczęściej w formie egzotycznej roślinności. [...] Typ B był znacznie „bardziej charakterystyczny, jednak bez cienia karykatury”, albowiem malarz prezentował „stosunek do modela obiektywny”. [...]

Typ C - Witkacy wykonywał głównie dla przyjaciół, w sytuacjach towarzyskich, z reguły pod wpływem alkoholu czy narkotyków. Dzięki „subiektywnej charakterystyce modela” dochodziło do „spotęgowania karykaturalnego tak formalnie, jak i psychologicznie”.

Portret typu D był imitacją poprzedniego, tyle, że malowany bez wspomagania farmakologicznego. [...] Oddzielnym rodzajem były portrety typu E. Była to „dowolna interpretacja psychologiczna według intencji firmy" . 
Klasyczny w ujęciu portret przedstawiający Marię Nawrocką z I925 roku można postawić w pewnego rodzaju opozycji formalnej wobec luźnej interpretacji kolorystycznej ujętego w sposób bardzo daleki od realizmu drugiego portretu Nawrockiej Z I926 roku, którego powstawaniu towarzyszyly dodatkowe substancje „wspomagające”, takie jak: $\mathrm{C}_{2} \mathrm{H}_{5} \mathrm{OH}$ i narkotyki „wyższego rzędu”.

W czasach współczesnych Witkacemu jego „przemiany” narkotycznej świadomości uchodziły za rodzaj artystycznej wizji, dziwactwa czy też po prostu dowód znacznego oderwania od rzeczywistości.

Przemianami w szeroko pojętej sztuce współczesnej są zachodzące na przestrzeni ostatniego stulecia interpretacje obiektów zaliczanych do grona Wielkich Dzieł Sztuki. Owe zmiany zaszły tak daleko i rozumiane są tak szeroko, że trudno o jednoznaczną definicję tego, czym obecnie jest dzieło sztuki. Definicję taką próbują zapewne stworzyć krytycy i teoretycy, marszandzi czy nawet sami artyści, nie jest to jednak ani łatwe, ani jednoznaczne wobec braku granic, w jakich sztuka współczesna może się poruszać. Współczesną przemianą w sztuce, podsumowującą ten problem w sposób najszerszy, jest zatem z pewnością założenie, że sztuką może być wszystko, co zostanie zakwalifikowane do jej miana. Jak daleko zatem może się posunąć owa transformacja? $\mathrm{Na}$ to pytanie odpowiedzieć może jedynie historia „sztuki przyszłej”, która z oczywistych względów nie jest w tym momencie możliwa do zdefiniowania.

\section{Bibliografia:}

[b.a.], Wielcy malarze - Claude Monet, Kraków 1998, nr 2;

[b.a.], Wielcy malarze - Leonardo da Vinci, Kraków 1999, nr 37;

Janson H.W., Historia sztuki od czasów najdawniejszych po dzień dzisiejszy, tłumacze różni, Warszawa 1993;

Koper S., Życie prywatne elit artystycznych Drugiej Rzeczypospolitej, Warszawa 2010;

Leksykon malarstwa (XIX i XX wiek), red. nauk. P. Szubert, Warszawa 1992;

Stone I., Udręka i ekstaza, tłum. A. Szpakowska, Warszawa 1990.

SŁowa KLucze: przemiany, proces twórczy, Michał Anioł, Leonardo da Vinci, Claude Monet, Witkacy (Stanisław Ignacy Witkiewicz) 


\section{Katarzyna Stanny}

\section{The nature of transformations in the Fine Arts}

This paper aims to portray a remarkably diverse range of phenomena related to transformations in art: from the transformation of sculptor's or painter's matter into a work of art (on the example of works of Michelangelo and Leonardo da Vinci), through the spiritual metamorphosis of the artist whilst creating a piece, up to reciprocal flow of inspirations, feelings, emotions, and consciousness or its absence on the creation of the artefact that shapes the spiritual experiences of the audience. During the human engagement in the work of art, those phenomena can also occur with respect to faith by means of an artistic expression of a purely religious character (e.g. Vatican's monumental and magnificent architecture).

"The aging" of a piece of art or restoration activities that block this aging are examples of changes of the matter owing to the technology that changes the perception of the work over time; while, art devoted to glorifying - and inducing - social evolutions and revolutions is in the service of propaganda and politics (e.g. works created in ancient Egypt, the Third Reich, North Korea, the USSR).

Artistic visions often depend on the influences of psychoactive substances on the consciousness of the artist and his perception of reality which results in its completely different reception (Witkacy's portraits). Is such artistic vision created under the influence of substances objective? Where (if at all) in the modern world can we trace boundaries between art and non-art? This text aims to address and answer these questions and doubts.

KeYwords: transformations, the creative process, Michelangelo, Leonardo da Vinci, Claude Monet, Witkacy (Stanisław Ignacy Witkiewicz) 